\title{
Early Holocene decadal-scale ocean variability recorded in Gulf of California laminated sediments
}

\author{
Jennifer Pike and Alan E. S. Kemp \\ Department of Oceanography, University of Southampton, Southampton Oceanography Centre \\ Southampton, England
}

\begin{abstract}
Scanning electron microscope examination of Holocene laminated sediment from Guaymas Basin, Gulf of California, resolves up to five depositional events per year. Each lamina/sublamina of an early Holocene section of continuously laminated sediment was recorded from backscattered electron imagery photomosaic analysis. Diatom mat laminae, composed predominantly of Thalassiothrix longissima, are associated with early winter mixed diatom flora laminae. Mats are probably brought into the Gulf with Pacific water during the summer, concentrated at the surface or at the pycnocline, and then rapidly deposited in the early winter as water column stratification breaks down. Time series analysis of one -300 -year section from piston core JPC56 revealed significant periodicities in the deposition of mat laminae at $\sim 50$ years, $\sim 11$ years, and 22-24 years. An 50-year cycle in fish populations has been related to changing North Pacific ocean/atmosphere circulation. These Pacific-wide changes in circulation affect the currents dominant at the mouth of the Gulf. When the California Current is dominant, fewer diatom mats are imported into the Gulf, and when the north equatorial Pacific gyre is dominant, more are imported. The $\sim 11$-year, 22- to 24-year, and $\sim 50$-year cycles are all suggested to be influenced by solar cycles.
\end{abstract}

\section{Introduction}

Records of interannual variability in laminated marine and lacustrine sediments are being increasingly exploited in the study of short timescale cyclicity and rapid climate change. The evolution of laminated sediment studies in the twentieth century, together with increasing sophistication of analytical methods, has reflected an increasing awareness of the dominance of the annual cycle. Early studies of varves for correlation and as chronometers were broadened to include time series analysis of varve thickness measurements (see review by Anderson [1996]). More recently, image analysis techniques have enabled rapid time-series analysis of laminated sediments [e.g. Ripepe et al., 1991; Thurow and Schaaf, 1995; Hughen et al., 1996]. These studies have typically been based on sediment core surfaces, X-ray radiographs of sediment slabs, or optical microscopy of thin sections, or peels. As such, this work has generally not exploited the highest-resolution information available from varves, some of which contain

Copyright 1997 by the American Geophysical Union.

Paper number 96PA03132.

0883-8305/97/96PA-03132\$12.00 records of multiple seasonal events. The recent application of backscattered electron imagery (BSEI) to laminated marine sediments has facilitated the identification of regular intra-annual components, of the order of tens of microns in thickness, such as sublaminae of different microfossil species that record seasonal species successions or multiple bloom events [Bull and Kemp, 1995; Kemp, 1995; Pike and Kemp, 1996b]. The validation of such records by comparison with sediment trap time series has added a new perspective to analysis of interannual variability.

The purpose of this paper is to report the results of scanning electron microscope-based time series analysis of different microfossil components in sublaminae of one -300-year sediment section from JPC56, a piston core from the Guaymas Basin, Gulf of California. The exceptional intra-annual record of surface ocean/climate variability recorded in central Gulf laminated sediments, documented by BSEI analysis, provides an ideal time series for investigations of variability on interannual to decadal timescales.

\section{Oceanographic Setting}

The Gulf of California (northwest Mexico) is a semienclosed sea, marginal to the Pacific Ocean, which is 

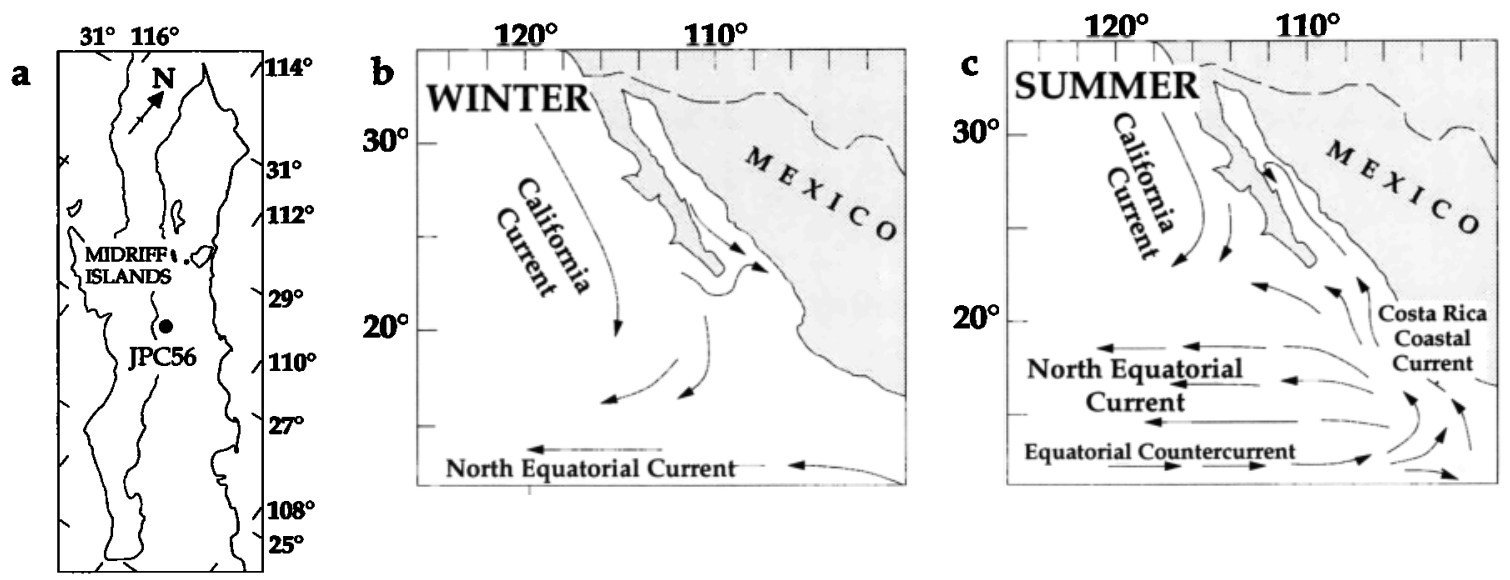

Figure 1. Maps showing (a) the location of piston core JPC56; (b) schematatic representation of eastern Pacific and Gulf surface water circulation patterns during the winter season (strong northwesterly winds in the Gulf and flow of surface water out); (c) schematic representation of eastern Pacific and Gulf surface water circulation patterns during the summer season (weaker, southerly winds associated with a flow of surface water into the Gulf from the tropical eastern Pacific). (Figures $1 \mathrm{~b}$ and 1c modified after Schrader and Baumgartner [1983]).

divided bathymetrically into two sections by the Midriff Islands (Figure 1a): the northern and the central and southern Gulf [Dauphin and Simoneit, 1991]. The central and southern Gulf comprises a series of basins silled at progressively greater depths from northwest to southeast, which are in open communication with the Pacific [Rusnak et al., 1964]. The proximity of the Sonora Desert and arid Baja California peninsula gives the Gulf a continental, rather than oceanic, climate, with dry winter and relatively wet, stormy summer seasons [Roden, 1964].

The reversal of seasonal winds and the breakdown of the thermocline in the fall mark the beginning of high productivity in the Gulf [Thunell et al., 1993]. The ensuing spring upwelling of nutrient-rich Gulf Water ([Baumgartner, 1987] formed in the northern Gulf/Midriff Islands region during winter [Bray, 1988]) along the eastern coastline also promotes high primary productivity in the euphotic zone [Alvarez-Borrego and Lara-Lara, 1991]. The subsequent rain of organic debris enhances the oxygen minimum zone (OMZ) (characteristic of Pacific Intermediate Water at the eastern tropical Pacific continental margin [Wyrtki, 1962, 1967]) so that in the central and southern Gulf, dissolved oxygen concentrations are $<0.5 \mathrm{~mL} \mathrm{~L}^{-1}$ at depths of less than $150 \mathrm{~m}$ and are almost undetectable at intermediate depths (500-1100 m) [Roden, 1964].

\section{Sedimentation}

The Gulf is characterized by opal-rich sediments [Calvert, 1966a; Thunell et al., 1994], and diatom ooze dominates slope and basin deposits [Bandy, 1961]. Slope sediments are often laminated where the OMZ intersects the seafloor [Calvert, 1964]. Early workers suggested that biogenic opal flux to the sediment varied (high surface productivity in winter/spring, low surface productivity in summer/autumn) with constant terrigenous flux from the rivers discharging into the Gulf [Byrne and Emery, 1960; Revelle, 1950], and that terrigenous flux varied (high in summer/autumn, low in winter/spring) with constant flux of opal [Calvert, 1966b]. It is now clear, from Deep Sea Drilling Project (DSDP) Leg 64 results [Curray et al., 1982] and sediment trap studies [Thunell et al., 1993], that both biogenic opal and lithogenic flux varies. Opal flux to the sediment is highest during early winter, lower during spring, and at a minimum during the summer/autumn, with lithogenic flux low in winter/spring and high in summer/autumn [Donegan and Schrader, 1982; Thunell et al., 1993]. Aeolian input of sediment during the summer (in response to convective thunderstorms over the Sonora Desert) is more important than fluvial input [Baumgartner et al., 1991]. Recent sediment trap data and sediment laminae studies from the Gulf [Sancetta, 1995; Thunell et al., 1993] (Figure 2), have demonstrated that the annual flux cycle has three main components: (1) a summer/autumn lithogenic flux (deposited during the rainy season); (2) an early winter flux consisting of mixed diatom flora (deposited as summer stratification breaks down and wind mixing brings nutrient-rich water into the euphotic zone); and (3) a flux composed of a near-monospecific diatom flora (deposited during, or 


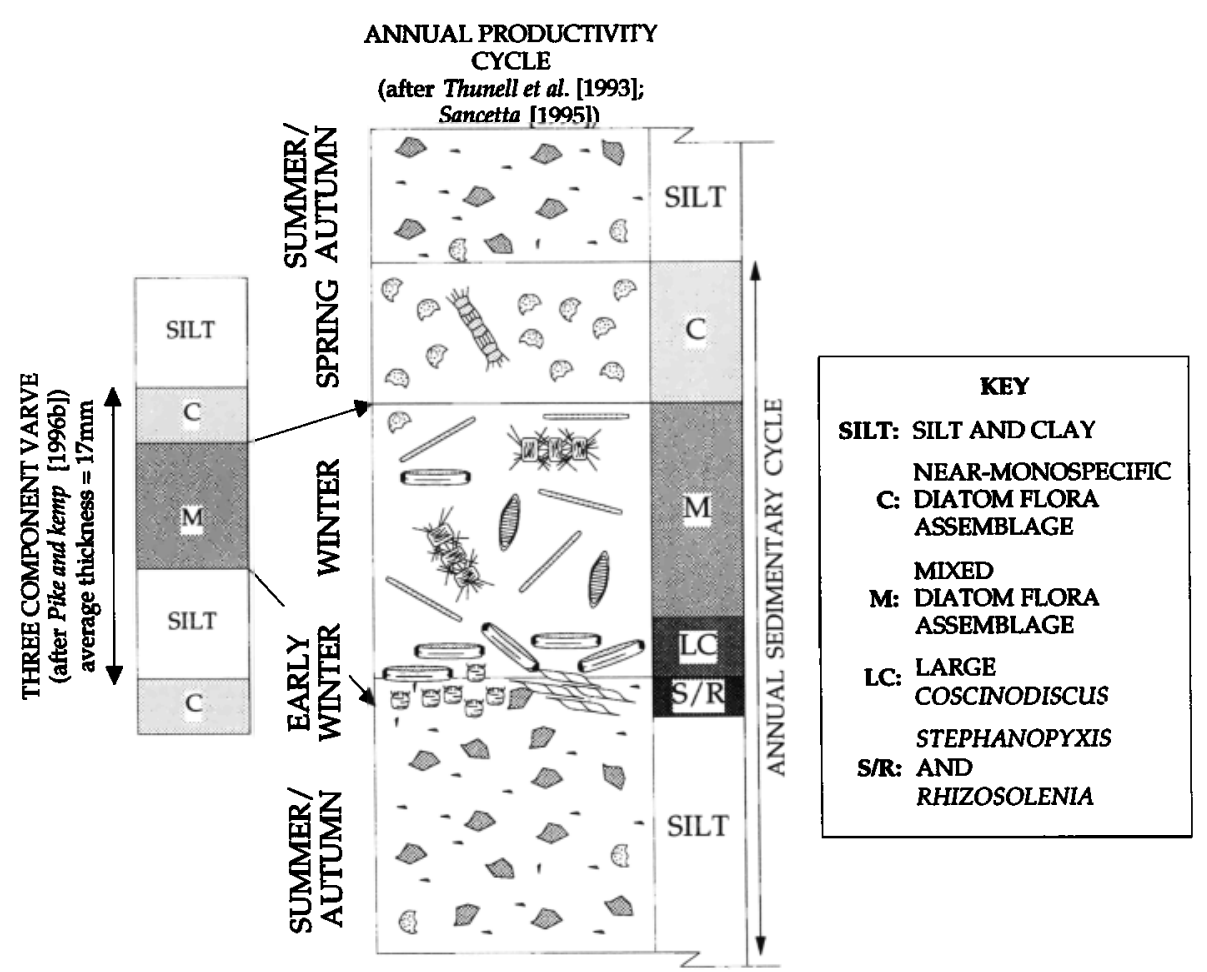

Figure 2. Schematic representation of the annual productivity/sedimentation cycle compiled from backscattered electron imagery [Pike and Kemp, 1996b] and sediment trap [Sancetta, 1995; Thunell et al., 1993] data.

directly following, the spring coastal upwelling season) (Figure 2). On the basis of multiple years of sediment trap data, it has become apparent that there is also a secondary peak in lithogenic flux in the winter (R.C. Thunell, unpublished data, 1996).

\section{Backscattered Electron Imagery Studies of Gulf Sediments}

Backscattered electron imagery (BSEI) analysis of Holocene sediments from Guaymas Basin have demonstrated that the three-component annual productivity/sedimentation cycle documented in sediment traps is preserved in the laminae throughout much of the Holocene [Pike and Kemp, 1996b]. Further detailed BSEI analysis reveals that the mixed flora diatom laminae are commonly composite, with up to three internal sublaminae containing distinct diatom species/assemblages Near-monospecific sublaminae of Rhizosolenia spp. and Stephanopyxis palmeriana are often preserved within the very top of summer silt laminae, and large Coscinodiscus spp. sublaminae are preserved directly above the silt (Figure 2). These taxa bloom with the first input of new nutrients into the surface waters, as the thermocline breaks down [Sancetta, 1995]. Distinct sublaminae of diatom mats, composed predominantly of Thalassiothrix longissima, are intermittently present as a component within the mixed flora laminae. The origins and variation in occurrence of these diatom mats are the subject of this study.

\section{Materials and Methods}

Jumbo piston core JPC56 (27 $28.16^{\prime} \mathrm{N}$; $\left.112^{\circ} 06.26^{\prime} \mathrm{W}\right)$ was recovered from the western Guaymas Basin slope in 1990 during R/V Atlantis II Leg 125/8 and split and archived at Woods Hole Oceanographic Institution. A 50cm-long section (JPC56, $502-552 \mathrm{~cm}$, hereinafter referred to as the JPC56 section) of continuously laminated sediment was sampled for this study (Figure 3). Eleven accelerator mass spectrometry (AMS) radiocarbon dates, from planktonic foraminifers, for JPC56 (L. D. Keigwin, unpublished data, 1995) were converted to calibrated years B.P. using the program CALIB3.0.3c with a laboratory correction $(f)$ of 60 years (Stuiver and Reimer [1993], incorporating the data of Bard et al. [1993]). A reservoir correction of $920 \pm 40$ years was used (see Stuiver and Brazunias [1993]). A best-fit line ( $R=0.98)$ gives a length for the JPC56 section of 300 years and an age from 9200 to 9500 calibrated years B.P. Using both the BSEI-derived 


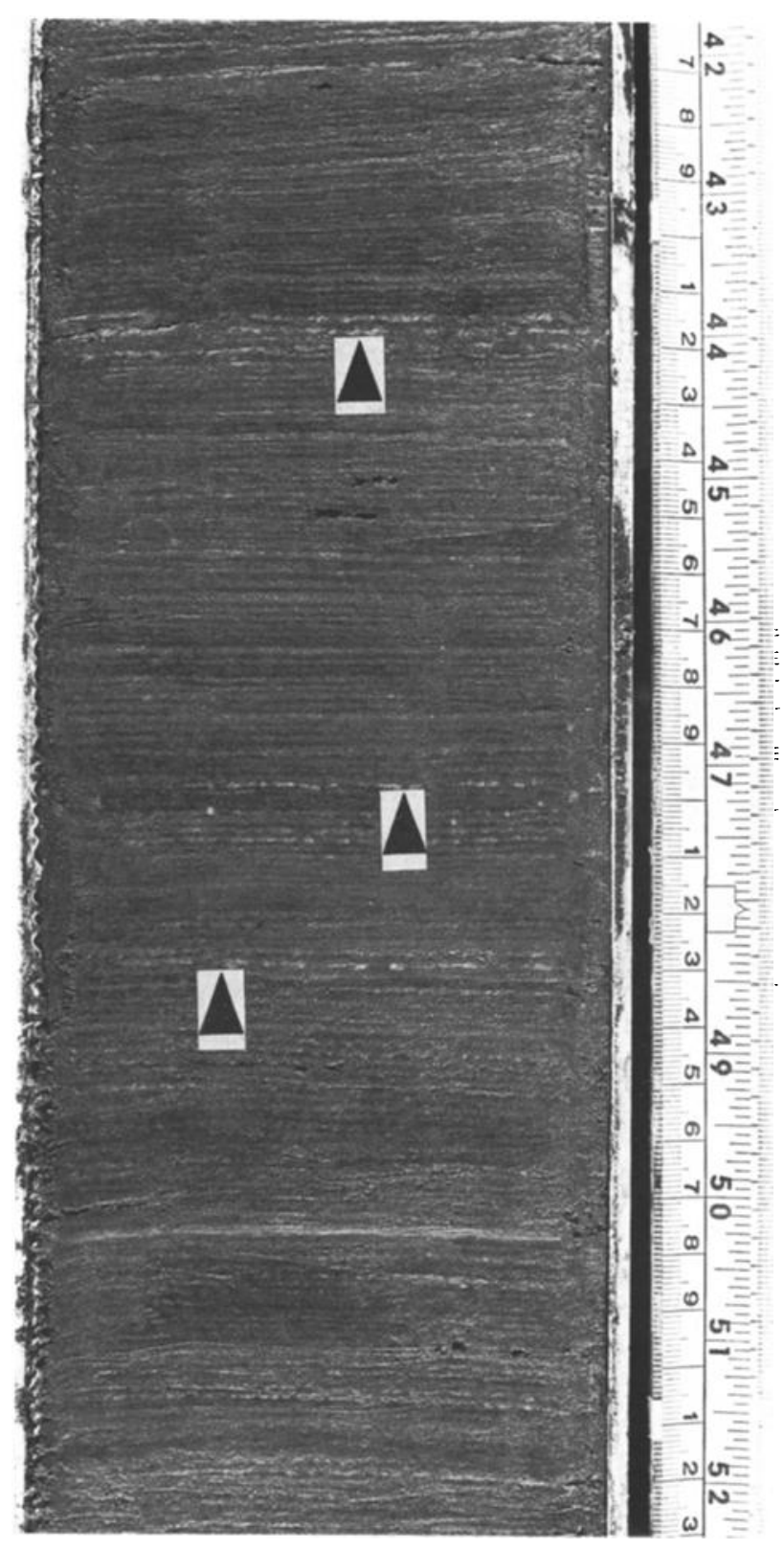

Figure 3. Core photograph of laminated early Holocene diatom ooze from piston core JPC56, Guaymas Basin slope, Gulf of California. Arrows indicate ragged-edged diatom mat laminae (JPC56, 508-534 cm).

annual productivity cycle [Pike and Kemp, 1996b] and traditional varve counts from the thin sections, the JPC56 section represents 289 years of sediment.

Thin sections were prepared for scanning electron microscope (SEM) analysis using a low-viscosity Spurr resin, fluid displacive embedding technique [Pike and Kemp, 1996a]. BSEI analysis of thin sections and secondary electron imagery (SEI) analysis of lamina-parallel fractured surfaces were carried out following the procedures described by Pike and Kemp [1996a]. Each identifiable sublamina was logged from the BSEI photomosaic, the presence of clays/silt and diatom species was noted, and thickness was measured. Smear slides of diatom mat fragments were made, using Naphrax highresolution diatom mountant (refractive index 1.74), to examine the species composition.

\section{Position of Diatom Mats in the Annual Productivity Cycle}

When core JPC56 is examined by visual inspection, numerous pale olive "ragged-edged" laminae can be seen (Figure 3), as well as small (few millimeter diameter), pale olive, paper-like blebs lying on the core surface. The blebs represent parts of laminae that have been pulled out of the core by the wire during core splitting. Examination by BSEI reveals that the laminae are composed of predominantly pennate diatoms, with clays, silt and minor centric diatoms. SEI examination shows the laminae comprise several individual mats, predominantly composed of the diatom Thalassiothrix longissima. Optical microscopy of smear slides shows that the diatom assemblage of the mats is composed of $60-70 \% T$. longissima, $<10 \%$ T. acuta with T. mediterranea, and up to 30\% Thalassionema spp. (T. nitzschioides, T. nitzschioides var. parva, T. bacillaris, and T. frauenfeldii) (J. Pike and C. B. Lange, unpublished data, 1994).

BSEI photomosaics were used to identify the composition and thickness of every lamina and sublamina in the JPC56 section. Each lamina/sublamina, defined by the major diatom species present, was recorded in a lamina transition matrix, and then, from comparison with Recent sediment trap data [Sancetta, 1995], diatom species were grouped together by the time of year/oceanographic conditions they represent. For example, sublaminae of the diatoms Rhizosolenia spp., Stephanopyxis palmeriana, and some large (100-300 $\mu \mathrm{m}$ diameter) Coscinodiscus species were grouped together because they occur during the early winter stage of the annual productivity cycle. A final matrix comprising six categories, defined by oceanographic significance, was compiled (Table 1).

Laminae which follow one another (i.e., deposited sequentially), with similar composition but slightly different backscatter coefficient (i.e., brightness of the image, caused by discontinuities between laminae), were placed in the same category but not amalgamated as one lamina. The leading diagonal of the lamina transition matrix therefore cannot be zeros; the transition data cannot be treated as an embedded Markov chain, so standard tests for cyclicity cannot be applied [Carr, 1982; Powers and Easterling, 1982]. For this study, however, a simple 


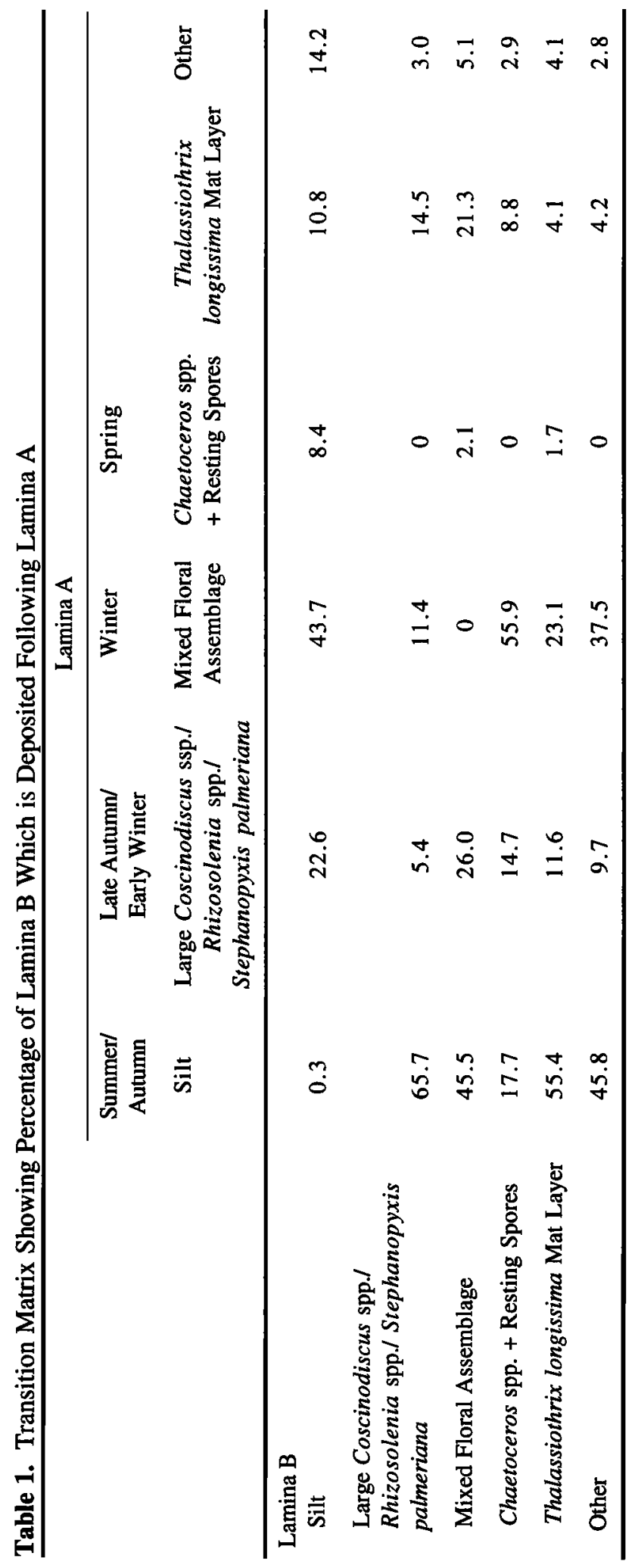

transition matrix was deemed sufficient, showing the percentage of occurrences of one category that are deposited following another (or the same) category (Table 1). The matrix shows that of the 119 occurrences of $T$. longissima diatom mat laminae in the JPC56 section, 67\% occur following either the summer/autumn silt lamina $(55.4 \%)$ or the early winter diatom species $(11.6 \%)$. The majority of the remaining diatom mat laminae are deposited after the winter mixed diatom flora assemblage.

\section{Ecology and Mechanism of Deposition of Thalassiothrix Diatom Mats}

Thalassiothrix longissima is a long (up to $4 \mathrm{~mm}$ ), thin (typically 3-4 $\mu \mathrm{m}$ ), open ocean, planktonic, pennate diatom. Cells may be solitary or may occur as tangled mats (Figure 4), and very little is known about the ecology of this diatom [Hallegraeff, 1986; Hasle and Semina, 1987; Round et al., 1990]. Studies of other mat formers, in particular rhizosolenid diatoms, show that they are adapted to stratified conditions and can regulate their buoyancy to retrieve $\mathrm{NO}_{3}{ }^{-}$from the nutricline and then return to the surface to photosynthesize [Villareal et al., 1993]. Low wind speeds (1-3 $\left.\mathrm{m} \mathrm{s}^{-1}\right)$ enhance the accumulation of buoyant mats at the surface [Villareal and Carpenter, 1989], and when buoyancy is lost, rapid downward transport of the mats, exceeding rates of $100 \mathrm{~m} \mathrm{~d}^{-1}$, takes place [Alldredge and Gotschalk, 1989; Sancetta et al., 1991].

Rhizosolenid mats were observed during the 1992 autumn Joint Global Ocean Flux Study (JGOFS) cruise in

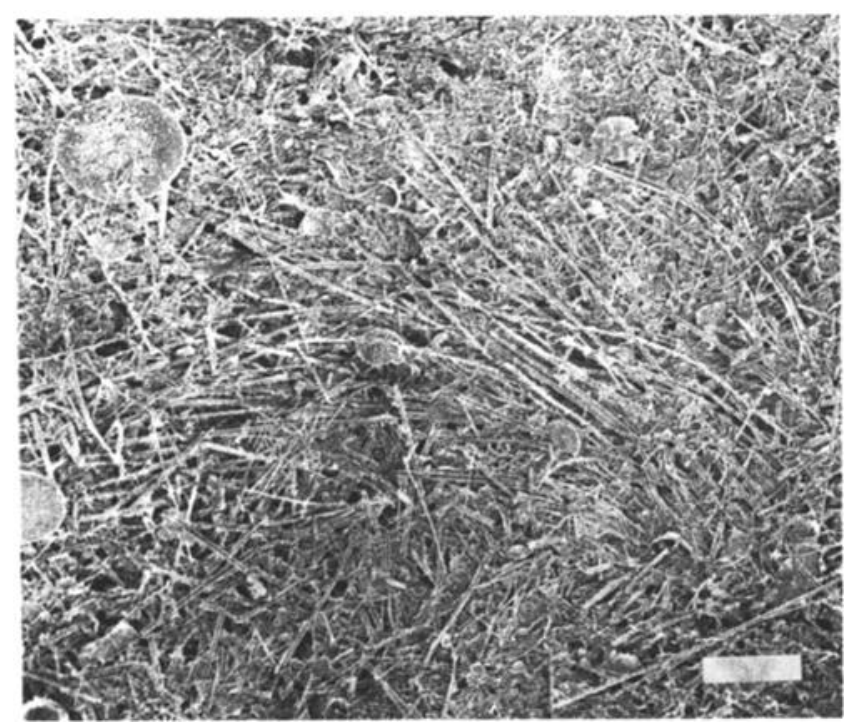

Figure 4. Secondary electron imagery photograph of $T$. longissima diatom mat $(\mathrm{scale} b a r=100 \mu \mathrm{m})$. 
the eastern equatorial Pacific aggregating into surface sheets, of several square kilometers, along a front $2^{\circ}$ north of the equator [Barber, 1992; Yoder et al., 1994]. Vast Neogene $T$. longissima diatom mat deposits have been documented in the eastern equatorial Pacific Ocean [Kemp and Baldauf, 1993]. By analogy with the JGOFS observations, the Neogene diatom mats are thought to have been concentrated along an oceanic front and subsequently deposited en masse, forming the thick laminated diatom mat deposits [Kemp et al., 1995]. A similar mechanism has been proposed for the deposition of late Quaternary laminated diatom ooze (also composed of $T$. longissima) in the North Atlantic [Bodén and Backman, 1996]. However, the Gulf of California is a semienclosed sea, and major frontal systems are restricted to the Ballenas Channel region [Badan-Dangon et al., 1985]. A frontal mechanism could not therefore explain the occurrence of mats in sediments across the entire central Gulf [Pike, 1996].

Diatom mat sublaminae most commonly occur during the early winter, following the summer/autumn silt deposition (Table 1). This time in the Gulf is characterized by strengthening winds, early winter storms, mixing of the upper water column, and breakdown of the strong summer thermocline/pycnocline [Thunell et al., 1993]. During the summer, diatom mats have been observed in the Gulf accumulating in streamers subparallel to the coast (T. R. Baumgartner, personal communication, 1994), presumably along the crests of internal waves set up as an infrequent

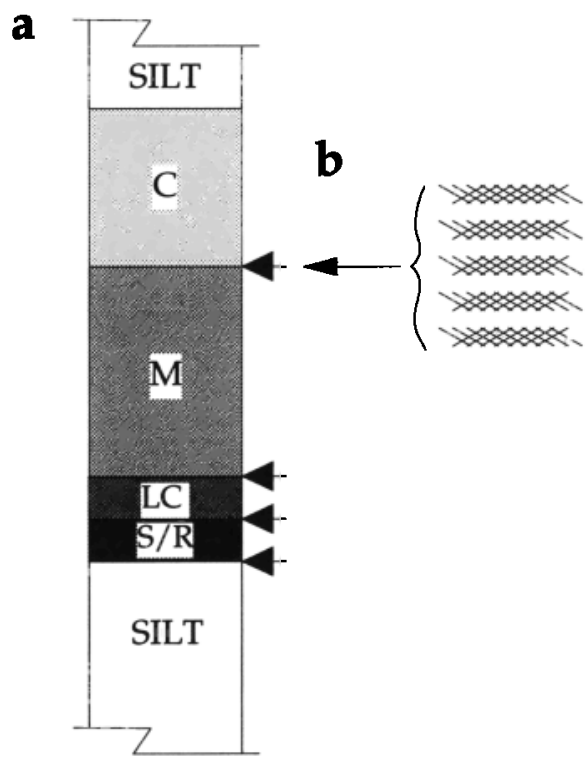

Figure 5. Schematic diagrams to show (a) the favored position of diatom mat laminae (indicated by arrows) within the annual sedimentation cycle and (b) how diatom mat laminae are composed of several individual diatom mats. summer upwelling cell relaxes [Kamykowski, 1974] and wind speeds drop [Villareal and Carpenter, 1989]. It is suggested here that $T$. longissima mats are brought into the Gulf with Pacific surface waters during the summer (Figure 1c); are either concentrated at the surface by internal waves and low wind speeds or sink and accumulate at the pycnocline, as described for marine snow off the southern California coast [Maclntyre et al., 1995]. The mats entrain a small proportion of the clays and silt being deposited in the Gulf at this time. Rapid sinking takes place when wind mixing breaks down the pycnocline [cf. Billett et al., 1983], depositing mats either on top of the summer/autumn silt or within the early winter diatomaceous laminae (Figure 5). A similar formation mechanism of rapid sinking of buoyant rhizosolenid and Chaetoceros spp. aggregates/mats after deep wind mixing has been suggested for diatom-containing sapropels of the eastern Mediterranean [Sancetta, 1994].

\section{Decadal Occurrence of Diatom Mats in Gulf of California Sediments} Time Series Analysis of the JPC56 Section

The number of $T$. longissima diatom mat laminae in each of the 289 years was recorded and varied from 0 to 4 (Figure 6a). These were defined as separate laminae, hence as separate depositional events, by either discontinuities or different backscatter coefficients from the SEM. The purpose of compiling and analyzing this time series was to extract any significant periodicities present in the occurrence of diatom mats in the early Holocene Gulf sediments in the simplest way possible. The expansion of a time series into the sum of a number of sine waves (by performing a Fourier transform (FT)) is the most elementary way of converting data from the time domain to the frequency domain; this does not alter the content of the time series, only the way it is displayed. The use of this expansion is valid for any time series which satisfies a set of conditions known as the Dirichlet conditions, i.e., the data have only a finite number of finite discontinuities and only a finite number of extreme values, maxima and minima (see [Arfken, 1985, p. 760]). The vast majority of time series observed in nature, including ours, satisfy these conditions. A linear regression was performed on the time series and the slope was subtracted from the graph to remove any long-term trend in the data ("prewhitening" [Chatfield, 1980, p. 160]). The detrended time series was transformed into a power spectrum using a discrete Fourier transform (DFT) using the MATLAB signal processing software (Figure 6b).

A DFT is a particular FT algorithm for analysis of a data set with values at discrete time intervals, in this case, the 
a

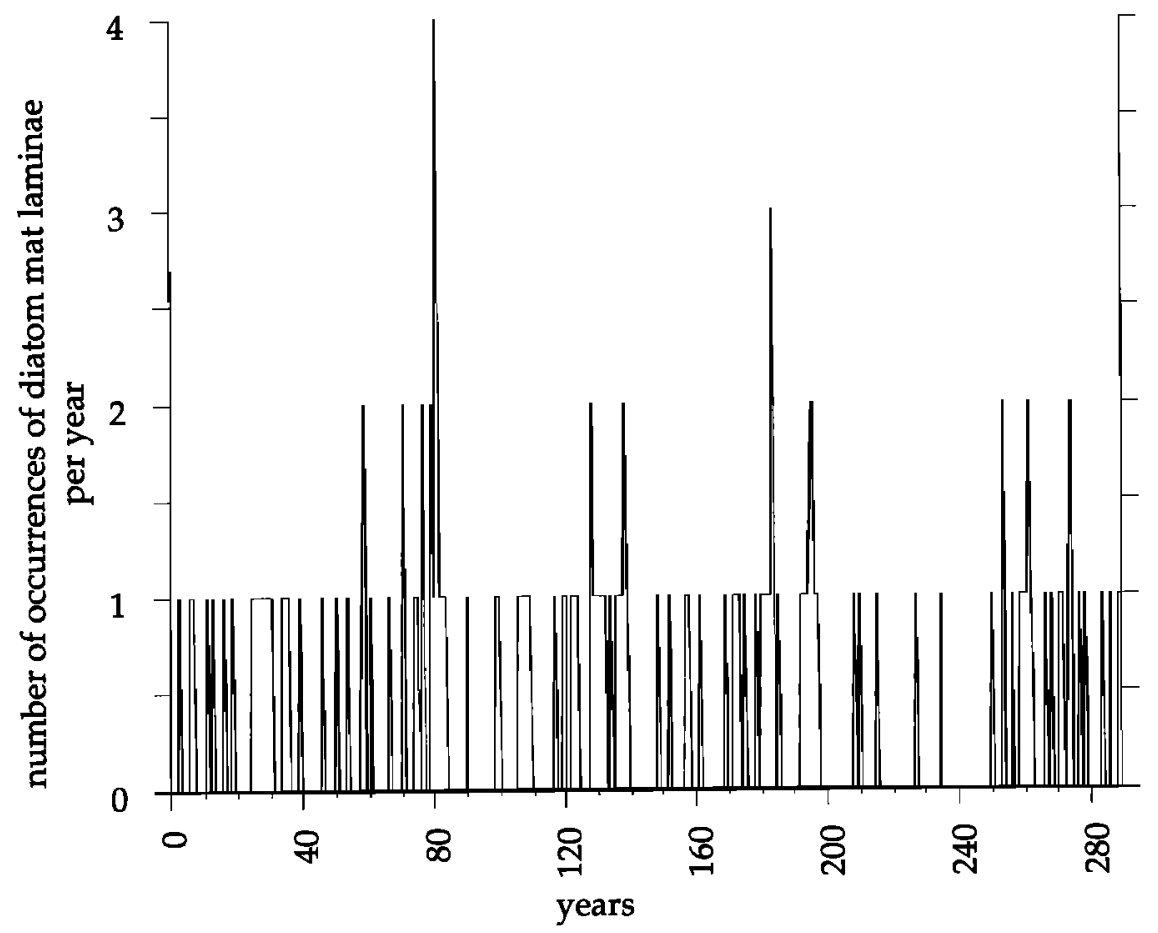

$\mathbf{b}$

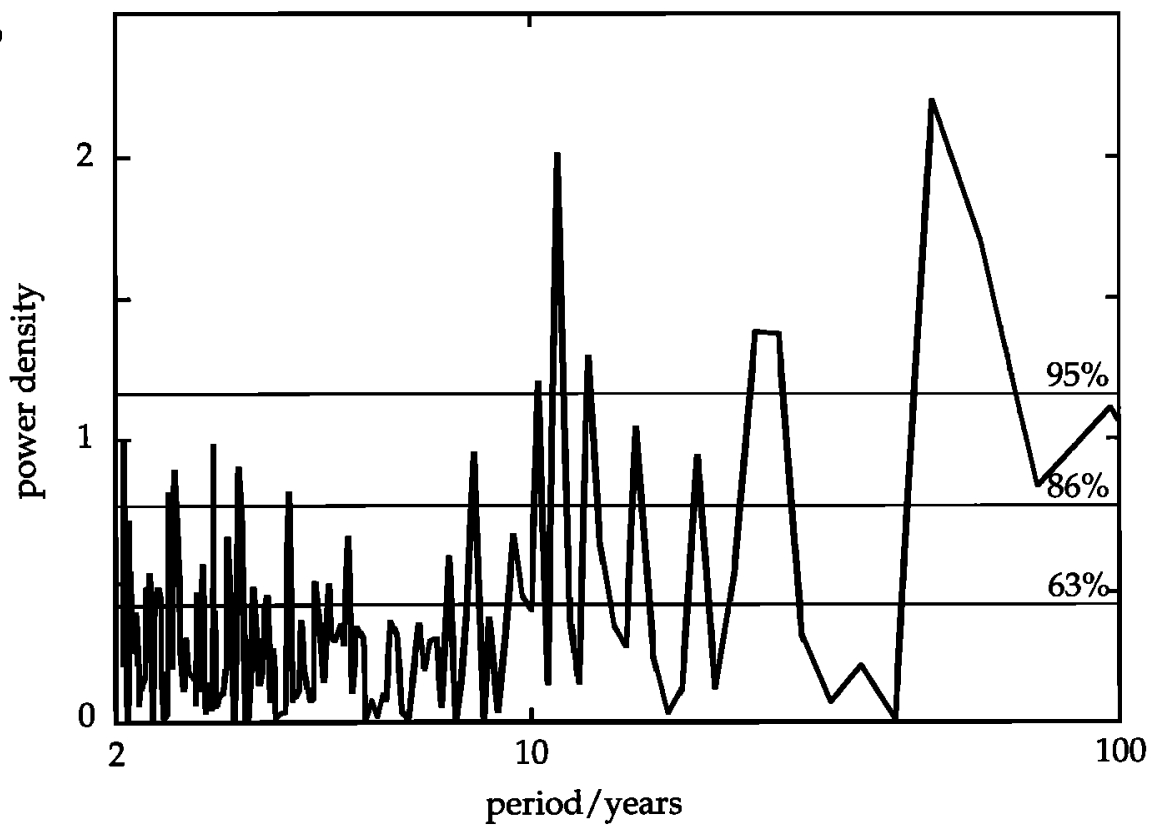

Figure 6. (a) Graph showing the number of occurrences of diatom mat laminae per year, throughout the JPC56 section, (b) Power spectrum for diatom mat occurrence in the JPC56 section.

number of diatom mats occurring per year. The DFT is similar to the more common fast Fourier transform (FFT) but differs in that it can be used with data sets of any length, not just those limited to lengths of $2^{n}$ where $n$ is an integer [Arfken, 1985, p. 791]. Use of an FFT here would necessitate either shortening the length of the series to $2^{n}$ or extending it by padding with zeros [cf. Hagadom et al., 1995]. Similarly, Walsh (square wave) transforms [Beauchamp, 1984] are mostly applied to millennial-scale "saw-toothed" records, such as oxygen isotope records of glacial-interglacial cycles [Tiwari, 1987], whereas our record is neither saw-toothed nor millennial-scale in length. Fast Walsh transforms also require $2^{n}$ data points, where $n$ is an integer [Tiwari, 1987]. Hence the DFT optimizes the 
analysis of our relatively short data set. One limitation to using a DFT with our data set could come from quantization error or, more correctly, quantization noise [Schwartz, 1980], because we are modeling the data as continuous sine waves, whereas observed values are restricted to integers (i.e., discrete levels), as discussed below.

The assumption behind our analysis is that the time series is composed of a small number of significant periodicities, together with a high proportion of noise, i.e., random variations. The noise in our time series comes from different sources such as random influences (i.e., probabilistic or stochastic, not deterministic, influences) on the occurrence of the diatom mats, measurement errors, and quantization noise. Quantization noise introduces noise into the power spectrum at high frequencies which are not important in our record (Figure 6b). It is beyond the purpose of this paper to consider this noise separately. All sources of noise are considered together, because we are only interested in extracting the signal from the noise, not in differentiating between the different sources of noise or their relative contributions.

This method of analysis provides confidence limits on the peak spectral estimates being real signals and not just noise (i.e., the probability that spectral peaks represent real periodicities rather than a combination of random variations). We assume that the statistical nature of the noise follows some theoretical noise model, and by comparing the statistics of our frequency spectrum with theory, we can verify whether the noise model is appropriate. We assume that the noise is white noise, which has a flat power spectrum (equal power at all frequencies) [Schwartz, 1980, p. 347] and describes entirely random processes [Chatfield, 1980, p. 39]. This analysis method is used because the time series is dominated by noise with only a very few significant periodicities. If the time series was dominated by many signals with a low level of noise, the statistics would not agree with the white noise model and this method would be inappropriate.

To show that the noise in our series is white (i.e., to verify our noise model), we examined a histogram of the spectral power estimates and compared this to the statistical probabilities given by the theory of white noise [Schwartz, 1980, pp. 611-615]. By showing that the two are similar, we verified our noise model (see Pike [1996] for a fuller explanation of the statistical methods used). The horizontal lines in Figure $6 \mathrm{~b}$ are at values of 1, 2, and 3 standard deviations of noise power and they represent confidence limits of $63.2 \%, 86.5 \%$, and $95.0 \%$, respectively, that the peaks are real periodicities rather than noise. For example, consider the peak in the power spectrum (Figure 6b) around 50 years. This peak lies above the $95 \%$ confidence limit; thus we can say with greater than $95 \%$ confidence that this is a real periodic signal and is less than $5 \%$ likely only to be due to a random combination of noise. Peaks that are significant at the $95 \%$ level represent periods of about 50 years (peak with the strongest power), 22-24 years, and approximately 11 years.

\section{Climate/Ocean Cycles With Approximately 11-, 22-, and 50-Year Periods}

Periodicities of 11 and 22 years are not uncommon in long-term climate and natural proxy climate records (Table 2). For example, productivity cycles in laminated sediments from Santa Barbara Basin [Lange et al., 1990] and laminae thickness in lacustrine sediments [Halfman and Johnson, 1988] both have periods of around 20 years. Cycles with periods of 11 and 22 years are generally ascribed to the 11-year sunspot cycle and the 22-year double sunspot, or Hale magnetic, cycle [Burroughs, 1992]. From harmonic analysis of sunspot numbers over the last 3000 years, it is known that important periodicities in the sunspot cycle exist around 11, 57, and 96 years [Berger et $a l ., 1990]$. The change in the Sun's irradiance during the sunspot cycle, however, is $<0.1 \%$, an order of magnitude too small to explain these periodicities when observed in climate records [Burroughs, 1992]. Amplification of this signal in the atmosphere is required if solar cycles influence the climate.

Changes in solar irradiance are concentrated in the UV region, wavelengths that are largely absorbed in the atmosphere, which could enhance the impact of the Sun on climate. Sources of UV in the Sun are associated with regions of intense magnetic activity [Burroughs, 1992]. Cycles of $\sim 22$ years have been more prevalent in climate and proxy climate records (including varve series [Anderson and Koopmans, 1963]) than the 11-year cycle. It is also the dominant feature in the global marine temperature record, and it has been suggested that a magnetic process is involved in the amplification of the effect of solar variability on climate [Burroughs, 1992].

Climate cycles of around 50 years, in the southwestern United States and the bordering ocean, have been reported from tree ring data and drought records, laminated marine and lake sediments, and fish scale deposition (Table 2). A periodicity of between 50 and 75 years in anchovy and sardine populations has been documented from laminated Santa Barbara Basin sediments over the last 2000 years [Baumgartner et al., 1992; Soutar and Isaacs, 1969]. Anchovies are more dominant for about 30 years and then go into decline, while sardines increase to become 
Table 2. A Selection of Climate and Natural Proxy Climate Records With Periodicities Similar to Those Described From the Occurrence of Diatom Mat Laminae in the Gulf of California

\begin{tabular}{|c|c|c|}
\hline Reference & Record & Periodicity \\
\hline Ripepe et al. [1991] & varved oil shales (Eocene) & 11 years \\
\hline Thurow and Schaaf [1995] & laminated sediments, Guaymas Basin (late Pleistocene to Recent) & 11 years \\
\hline Enfield and Cid [1991] & $\begin{array}{l}\text { recurrence of stong/very strong El Niño events (using the } \\
\text { Quinn et al. [1987] record) }\end{array}$ & $9-12$ years \\
\hline Labitzke and van Loon [1990] & QBO-like oscillations in the atmosphere & 11 years \\
\hline Lange et al. [1990] & $\begin{array}{l}\text { biological productivity recorded in Santa Barbara Basin sediments } \\
\text { (Holocene) }\end{array}$ & $\sim 20$ years \\
\hline Anderson et al. [1990] & $\begin{array}{l}\text { bioturbation in laminated sediments off coast of northern } \\
\text { and central California (late Pleistocene) }\end{array}$ & $\sim 20$ years \\
\hline Mitchell et al. [1979]; Meko [1992] & tree rings/drought in westem United States & 22 years \\
\hline Anderson et al. [1992] & varved marine and lacustrine sediments & $\sim 22$ years \\
\hline Anderson [1992a]; Quinn [1992] & Nile flood level (Holocene) & 22 years \\
\hline Anderson $[1992 b]$ & laminated sediments, Elk Lake (Holocene) & $20-25$ years \\
\hline Halfman and Johnson [1988] & laminated sediments, Lake Turkana & 25 years \\
\hline Anderson $[1992 b]$ & laminated sediments, Elk Lake (Holocene) & $40-50$ years \\
\hline Anderson [1992a]; Quinn [1992] & Nile flood level (Holocene) & 50 years \\
\hline Thurow and Schaaf [1995] & laminated sediments, Guaymas Basin (late Pleistocene to Recent) & 52.6 years \\
\hline Meko [1992] & tree rings/drought in western United States & 57 years \\
\hline Baumgartner et al. [1992] & sardine/anchovy scale deposition, Santa Barbara Basin (Holocene) & $\sim 60$ years \\
\hline Sharp [1992] & sardine populations around the Pacific Basin (Holocene) & $\sim 60$ years \\
\hline Schlesinger and Ramankutty [1994] & global mean surface temperature measured in North America & $65-70$ years \\
\hline
\end{tabular}

dominant. These 50- to 70-year cycles in anchovy/sardine fish populations have been related to Pacific basin-wide changes in atmospheric and oceanic circulation [Baumgartner et al., 1994]. As the Aleutian low-pressure area intensifies relative to the central Pacific high, the California Current (CC) weakens and moves offshore, accompanied by a decrease in biological productivity, less mixing, and weaker coastal upwelling [Lange et al., 1990]. As the Aleutian low weakens, the $\mathrm{CC}$ strengthens and moves back nearer shore. These longer-period shifts in the Pacific current system at the mouth of the Gulf mimic the seasonal cycle (Figure 1). During decades when the equatorial Pacific waters have more influence ("summer" condition, Figure 1c), it is likely that more $T$. longissima diatom mats would be transported into the Gulf each year than during the decades when the $\mathrm{CC}$ was more influential ("winter" condition, Figure 1b). Thus, by analogy with the late Holocene circulation pattern, early Holocene diatom mats preserved in Gulf sediments are recording decadal cyclicity in eastern Pacific circulation.

A study of laminated lake sediments from Elk Lake, Minnesota, revealed a possible mechanism for producing climate cycles of 20-25 and 50 years [Anderson, 1992b]. The varve thickness (a proxy for paleowind strength) and ${ }^{14} \mathrm{C}$ (a proxy for solar activity) tree ring records both show cycles of $\sim 50$ years during a period in the mid-Holocene when the Earth's magnetic field was relatively weak. Analysis of sunspot numbers reveals an important period in the sunspot cycle of 57 years [Berger et $a l ., 1990]$, and cycles in the occurrence of coronal mass ejections of $\sim 50$ years have been suggested as influencing proxy climate records [Anderson, 1992b]. It is possible therefore that solar cycles are influencing climate and ocean circulation cycles of around 50 years in the Pacific. 
The $\sim 11-, 22-$ to 24 - and $\sim 50$-year periods in the occurrence of diatom mat sublaminae are commonly found in long-term precipitation (e.g., tree rings [Meko, 1992]) and sea surface temperature (SST) (e.g., coral [Dunbar et al., 1994]) records that also include strong El NiñoSouthern Oscillation (ENSO) signals. ENSO has a profound effect on SST, sea level, water column structure, and biological population composition in the eastern equatorial Pacific [Barber and Chavez, 1983; Karl et al., 1995; McGowan, 1983], and all modern interannual variability in sea level and SST records in the Gulf is also attributable to ENSO [Baumgartner and Christensen, 1985]. The primary ENSO cycle of 3-7 years is not significant $(95 \%$ level) in the power spectrum (of the occurrence of diatom mats in the Gulf sediments); however, peaks of spectral power do occur about 3 years and 8 years at the $86 \%$ significance level (Figure 6b). In the early Holocene, fire, precipitation, and pollen records from Australasia and South America suggest that ENSO was less frequent in the southern midlatitudes [McGlone et al., 1992]. If this was the case, events would also be less frequently recorded in northern latitudes. It has been suggested that only the strongest equatorial ENSO events have a significant effect on the CC today [Simpson, 1984], and in the Quinn et al. [1987] historical record of El Niños, strong and very strong events occur with a frequency of 9-12 years [Enfield and Cid, 1991]. Any link between ENSO and the occurrence of diatom mats in the Gulf remains speculative. During the twentieth century, however, the Gulf has responded to ENSO dynamics with stronger incursions of Pacific surface waters [Baumgartner and Christensen, 1985]. Furthermore, throughout the Holocene, ENSO frequencies have been recorded from sedimentary color time series [Thurow and Schaaf, 1995].

Solar modulation of ENSO has been suggested as a cause for reoccurrence of decadal periodicities in late Pleistocene varve/bioturbation cycles (proxy ENSO record) off the California coast [Anderson et al., 1990]. Considering the likely strong solar influence in the diatom mat record, it is possible that the presence of diatom mats in the Gulf during the early Holocene is recording a similar solarmodulated ENSO history.

\section{Conclusions}

BSEI analysis of Gulf of California laminated sediments revealed that varves are composed of a three-component alternation: (1) a summer/autumn lithogenic lamina; (2) an early winter mixed diatom flora lamina; and (3) a nearmonospecific diatom lamina deposited during the spring [Pike and Kemp, 1996b]. Further BSEI studies show that mixed diatom flora laminae are often composite, containing up to three sublaminae, and periodically including layers of Thalassiothrix longissima-dominated diatom mats.

During the early Holocene, diatom mats dominated by $T$. longissima were brought into the Gulf with Pacific surface waters during the summer and were either concentrated at the surface or sank and accumulated at the pycnocline. When wind mixing weakened the pycnocline in the early winter, rapid sinking of the mats took place, depositing them either on top of the summer/autumn silt or within the early winter diatomaceous laminae.

Time series analysis of the occurrence of diatom mat laminae in the Gulf (during the early Holocene) revealed significant periodicities of $\sim 11$ years, 22-24 years, and, most strongly, at $\sim 50$ years. These periods are believed to be linked to solar cycles, although no clear mechanism exists for transmitting periodicities in the energy output of the Sun to the lower atmosphere.

The dominant $\sim 50$-year period in the early Holocene diatom mats is also recorded in fish population variability in California margin sediments, from the last 2000 years, which have been attributed to cyclic changes in North Pacific climate and ocean circulation [Baumgartner et al., 1994]. These changes in circulation, in turn, control whether the California Current or the North Equatorial Current is dominant at the mouth of the Gulf. Irrespective of whether there is a solar influence in these circulation patterns, the results of this paper demonstrate that similar 50-year climatic cycles were also a feature of Pacific circulation during the early Holocene.

Acknowledgments. J.P. acknowledges receipt of NERC Research Studentship GT4/92/263/G, and A.E.S.K. acknowledges receipt of NERC small grant GR9/203. We are grateful to Lloyd Keigwin for providing samples and unpublished AMS radiocarbon dates from core JPC56; to Carina Lange for invaluable help with diatom identification; to Ian Thomas for assistance with the statistics of the time series analysis (any errors are solely those of the authors); and to Connie Sancetta, Eelco Rohling, and Neil Wells for valuable discussions during different stages of this work. We thank Jim Gardner, Bob Thunell and an anonymous Associate Editor for their critical reviews of this manuscript. This paper is a contribution to IGCP 374: Palaeoclimatology and Palaeoceanography from Laminated Sediments. The time series data described in this paper have been archived and are available in a digital form from the World Data Center-A for Paleoclimatology, NOAA/NGDC, 325 Broadway, Boulder, CO 80303, USA (phone 303 $4976280 ;$ fax 3034976513 ; Internet email: paleo@mail.ngdc.noaa.gov).

\section{References}

Alldredge, A.L., and C.C. Gotschalk, Direct observations of the mass flocculation of diatom blooms: Characteristics, settling velocities and formation of diatom aggregates, Deep Sea Res., 36, 159-171, 1989.

Alvarez-Borrego, S., and J.R. Lara-Lara, The physical environment and primary productivity of the Gulf of California, in The Gulf and Peninsular Province of the Californias, edited by J.P. Dauphin and B.R.T. Simoneit, pp. 555-567, Am. Assoc. of Petrol. Geol., Tulsa, Okla., 1991.

Anderson, R.Y., Long-term changes in the frequency of occurrence of El Niño events, in El Niño: Historical and Paleoclimatic Aspects of 
the Southern Oscillation, edited by H.F. Diaz and V. Markgraf, pp. 193-200, Cambridge Univ. Press, New York, 1992a.

Anderson, R.Y., Possible connection between surface winds, solar activity and the Earth's magnetic field, Nature, 358, 51-53, 1992b.

Anderson, R.Y., Seasonal sedimentation: framework for reconstructing environmental and climatic change, in Palaeoclimatology and Palaeoceanography from Laminated Sediments, edited by A.E.S. Kemp, Geol. Soc. Spec. Publ., 116, pp. 1-15, 1996.

Anderson, R.Y., and L.H. Koopmans, Harmonic analysis of varve time series, J. Geophys. Res., 68, 877-893, 1963.

Anderson, R.Y., B.K. Linsley, and J.V. Gardner, Expression of seasonal and ENSO forcing in climatic variability at lower than ENSO frequencies: Evidence from Pleistocene marine varves off California, Palaeogeogr. Palaeoclimatol. Palaeoecol. 78, 287-300, 1990.

Anderson, R.Y., A. Soutar, and T.C. Johnson, Long-term changes in El Niño/Southern Oscillation: Evidence from marine and lacustrine sediments, in El Niño: Historical and Paleoclimatic Aspects of the Southern Oscillation, edited by H.F. Diaz and V. Markgraf, pp. 419434, Cambridge Univ. Press, New York, 1992.

Arkfen, G., Mathematical Methods for Physicists, 3rd ed., pp. 985, Academic, San Diego, Calif., 1985.

Badan-Dangon, A., C.J. Koblinsky, and T. Baumgartner, Spring and summer in the Gulf of Califomia: Observations of surface thermal patterns, Oceanol. Acta, 8, 13-22, 1985.

Bandy, O.L., Distribution of foraminifera, radiolaria and diatoms in sediments of the Gulf of California, Micropaleontology, 7, 1-26, 1961.

Barber, R.T., Fall survey cruise find cooling conditions in the equatorial Pacific, U.S. JGOFS News, 4.1, 1-6, 1992.

Barber, R.T., and F.P. Chavez, Biological consequences of El Niño, Science, 222, 1203-1210, 1983.

Bard, E., M. Amold, R.G. Fairbanks, and B. Hamelin, 230Th-234U and ${ }_{14 C}$ ages obtained by mass spectrometry on corals, Radiocarbon, 35 , 191-199, 1993.

Baumgartner, T.R., High resolution paleoclimatology from the varved sediments of the Gulf of California, Ph.D. thesis, Oreg. State Univ., Corvallis, 1987.

Baumgartner, T.R., and N. Christensen Jr., Coupling of the Gulf of California to large-scale interannual variability, J. Mar. Res., 43, 825-848, 1985.

Baumgartner, T.R., V. Ferreira-Bartrina, and P. Moreno-Hentz, Varve formation in the central Gulf of California: A reconsideration of the origin of the dark laminae from the 20th century varve record, in The Gulf and Peninsular Province of the Californias, edited by J.P. Dauphin and B.R.T. Simoneit, pp. 617-635, Am. Assoc. of Petrol. Geol., Tulsa, Okla., 1991.

Baumgartner, T.R., A. Soutar, and V. Ferreira-Bartrina, Reconstruction of the history of Pacific sardine and northem anchovy populations over the past two millennia from sediments of the Santa Barbara Basin, California, Rep. 33, pp. 24-40, Calif. Coop. Oceanic Fish. Invest., La Jolla, 1992.

Baumgartner, T., V. Ferreira, D. Cayan, and A. Soutar, Interdecadal variability of sardine and anchovy populations in the California Current (abstract), Eos, Trans. AGU, 75, Ocean Sci. Meet. Suppl., 34, 1994.

Beauchamp, K.G., Applications of Walsh and Related Functions With an Introduction to Sequency Theory, 308 pp., Academic, San Diego, Calif., 1984.

Berger, A., J.L. Melice, and L. van der Mersch, Evolutive spectral analysis of sunspot data over the past 3000 years, in The Earth's Climate and Variability of the Sun Over Recent Millennia, edited by J.C. Pecker and S.K. Runcorn, pp. 529-541, R. Soc., London, 1990.

Billett, D.S.M., R.S. Lampitt, A.L. Rice, and R.F.C. Mantoura, Seasonal sedimentation of phytoplankton to the deep-sea benthos, Nature, 302, 520-522, 1983.

Bodén, P., and J. Backman, A laminated sediment sequence from northern North Atlantic Ocean and its climatic record, Geology, 24, 507-510, 1996

Bray, N.A., Watermass formation in the Gulf of California, J. Geophys. Res., 93, 9223-9240, 1988.

Bull, D., and A.E.S. Kemp, Composition and origins of laminae in late Quaternary and Holocene sediments from the Santa Barbara Basin, Proc. Ocean Drill. Program, Sci. Results, 146, part 2, 77-87, 1995.
Burroughs, W.J., Weather Cycles: Real or Imaginary?, 201 pp., Cambridge Univ. Press, New York, 1992.

Byme, J.V., and K.O. Emery, Sediments of the Gulf of Califomia, Geol. Soc. Am. Bull., 7I, 983-1010, 1960.

Calvert, S.E., Factors affecting distribution of laminated diatomaceous sediments in the Gulf of California, in Marine Geology of the Gulf of California, edited by T.H. van Andel and G.G. Shor, pp. 311-330, Am. Assoc. of Petrol. Geol., Tulsa, Okla., 1964.

Calvert, S.E., Accumulation of diatomaceous silica in the sediments of the Gulf of California, Geol. Soc. Am. Bull., 77, 569-596, 1966a.

Calvert, S.E., Origin of diatom-rich varved sediments from the Gulf of California, J. Geol., 74, 546-565, 1966b.

Carr, T.R., Log-linear models, Markov chains and cyclic sedimentation, J. Sediment. Petrol., 52, 905-912, 1982.

Chatfield, C., The Analysis of Time Series: An Introduction, 2nd ed., 268 pp., Chapman and Hall, New York, 1980.

Curray, J.R., et al., Initial Report Deep Sea Drilling Project. 64, 1313 pp., U.S. Govt. Print. Off., Washington, D.C., 1982.

Dauphin, J.P., and B.R.T. Simoneit, The Gulf and Peninsular Province of the Californias, 834 pp., Am. Assoc. of Petrol. Geol., Tulsa, Okla., 1991.

Donegan, D., and H. Schrader, Biogenic and abiogenic components of laminated hemipelagic sediments in the central Gulf of California, Mar. Geol., 48, 215-237, 1982.

Dunbar, R.B., G.M. Wellington, M.W. Colgan, and P.W. Glynn, Eastern Pacific sea surface temperature since 1600 A.D.: The $\delta 180$ record of climate variability in Galápagos corals, Paleoceanography, 9, 291-315, 1994

Enfield, D.B., and S.L. Cid, Low-frequency changes in El NiñoSouthern Oscillation, J. Clim., 4, 1137-1146, 1991.

Hagadorn, J.W., L.D. Stott, A. Sinha, and M. Rincorn, Geochemical and sedimentologic variations in inter-annually laminated sediments from Santa Monica Basin, Mar. Geol., 125, 111-131, 1995

Halfman, J.D., and T.C. Johnson, High-resolution record of cyclic climatic change during the past $4 \mathrm{ka}$ from Lake Turkana, Kenya, Geology, 16, 496-500, 1988.

Hallegraeff, G.M., Taxonomy and morphology of the marine plankton diatoms Thalassionema and Thalassiothrix, Diatom Res., 1, 57-80, 1986.

Hasle, G.R., and H.J. Semina, The marine planktonic diatoms Thalassiothrix antarctica with comments on Thalassionema spp. and Synedra reinboldii, Diatom Res., 2, 175-192, 1987.

Hughen, K.A., J.T. Overpeck, L.C. Peterson, and S. Trumbore, Rapid climate changes in the tropical Atlantic region during the last deglaciation, Nature, 380, 51-54, 1996.

Kamykowski, D., Possible interactions between phytoplankton and semidiumal internal tides, J. Mar. Res., 32, 67-89, 1974.

Karl, D.M., R. Letelier, D. Hebel, L. Tupas, J. Dore, J. Christian, and C. Winn, Ecosystem changes in the North Pacific subtropical gyre attributed to the 1991-92 El Niño, Nature, 373, 230-234, 1995.

Kemp, A.E.S., Laminated sediments from coastal and open ocean upwelling systems: What variability do they record?, in Upwelling in the Ocean: Modern Processes and Ancient Records, edited by C.P. Summerhayes, et al., pp. 239-257, John Wiley, New York, 1995.

Kemp, A.E.S., and J.G. Baldauf, Vast Neogene laminated diatom mat deposits from the eastern equatorial Pacific Ocean, Nature, 362, 141-144, 1993.

Kemp, A.E.S., J.G. Baldauf, and R.B. Pearce, Origins and paleoceanographic significance of laminated diatom ooze from the eastern equatorial Pacific Ocean (ODP Leg 138), Proc. Ocean Drill. Program Sci. Results, 138, pp. 641-645, 1995.

Labitzke, K., and $H$. van Loon, Associations between the 11-year solar cycle, the quasi-biennial oscillation and the atmosphere: A summary of recent work, Philos. Trans. R. Soc., London., Ser. A 330, 577-589, 1990.

Lange, C.B., S.K. Burke, and W.H. Berger, Biological production off southern California is linked to climate change, Clim. Change, 16, 319-329, 1990.

MacIntyre, S., A.L. Alldredge, and C.C. Gotschalk, Accumulation of marine snow at density discontinuities in the water column, Limnol. Oceanogr., 40, 449-468, 1995.

McGlone, M.S., A.P. Kershaw, and V. Markgraf, El Niño/Southern Oscillation climatic variability in Australasian and South American paleoenvironmental records, in El Niño: Historical and Paleoclimatic 
Aspects of the Southern Oscillation, edited by H.F. Diaz and V. Markgraf, pp. 435-462, Cambridge Univ. Press, New York, 1992.

McGowan, J.A., El Niño and biological production in the California Current, Trop. Ocean-Atmos. Newsl., 21, 23, 1983.

Meko, D.M., Spectral properties of tree-ring data in the United States Southwest as related to El Niño/Southern Oscillation, in El Niño: Historical and Paleoclimatic Aspects of the Southern Oscillation, edited by H.F. Diaz and V. Markgraf, pp. 227-242, Cambridge Univ. Press, New York, 1992.

Mitchell, J.M., Jr., C.W. Stockton, and D.M. Meko, Evidence of a 22year rhythm of drought in the western United States related to the Hale Solar Cycle since the 17th Century, in Solarterrestrial Influences on Weather and Climate, edited by B.M. McCormac and T.A. Seliga, pp. 125-143, D. Reidel, Norwell, Mass., 1979.

Pike, J., High resolution palaeoceanography and palaeoclimatology from late Pleistocene and Holocene laminated sediments, Gulf of California, Ph.D. thesis, Univ. of Southampton, Southampton, England, 1996.

Pike, J., and A.E.S. Kemp, Preparation and analysis techniques for studies of laminated sediments, in Palaeoclimatology and Palaeoceanography from Laminated Sediments, edited by A.E.S. Kemp, Geol. Soc. Spec. Publ., 116, pp. 37-48,1996a.

Pike, J., and A.E.S. Kemp, Records of seasonal flux in Holocene laminated sediments, Gulf of California, in Palaeoclimatology and Palaeoceanography from Laminated Sediments, edited by A.E.S. Kemp, Geol. Soc. Spec. Publ., 116, pp. 157-169, 1996b.

Powers, D.W., and R.G. Easterling, Improved methodology for using embedded Markov chains to describe cyclical sediments, $J$. Sediment. Petrol., 52, 913-923, 1982.

Quinn, W.H., A study of Southern Oscillation-related climatic activity for A.D. 622-1990 incorporating Nile River flood data, in El Niño: Historical and Paleoclimatic Aspects of the Southern Oscillation, edited by H.F. Diaz and V. Markgraf, pp. 119-150, Cambridge Univ. Press, New York, 1992.

Quinn, W.H., V.T. Neal, and S.E. Antunez de Mayolo, El Niño occurrences over the past four and a half centuries, J. Geophys. Res., 92, 14,449-14,461, 1987.

Revelle, R., Sedimentation and oceanography - Survey of field observations, in The 1940 E.W. Scripps Cruise to the Gulf of California, edited by C.A. Anderson, et al., pp. 1-6, Geol. Soc. of Am., Boulder, Colo., 1950.

Ripepe, M., L.T. Roberts, and A.G. Fischer, ENSO and sunspot cycles in varved Eocene oil shales from image analysis, J. Sediment. Petrol., 61, 1155-1163, 1991.

Roden, G.I., Oceanographic aspects of Gulf of California, in Marine Geology of the Gulf of California, edited by T.H. van Andel and G.G. Shor Jr., pp. 30-58, Am. Assoc. of Petrol. Geol., Tulsa, Okla., 1964.

Round, F.E., R.M. Crawford, and D.G. Mann, The Diatoms: Biology and Morphology of the Genera, 747 pp., Cambridge Univ. Press, New York, 1990.

Rusnak, G.A., R.L. Fisher, and F.P. Shepard, Bathymetry and faults of the Gulf of California, in Marine Geology of the Gulf of California, edited by T.H. van Andel, and G.G. Shor, pp. 59-75, Am. Assoc. of Petrol. Geol., Tulsa, Okla., 1964.

Sancetta, C., Mediterranean sapropels: Seasonal stratification yields high production and carbon flux, Paleoceanography, 9, 195-196, 1994.

Sancetta, C., Diatoms in the Gulf of California: Seasonal flux patterns and the sediment record for the past 15,000 years, Paleoceanography, 10, 67-84, 1995.

Sancetta, C., T. Villareal, and P. Falkowski, Massive fluxes of rhizosolenid diatoms: a common occurrence?, Limnol. Oceanogr., 36, 1452-1457, 1991.

Schlesinger, M.E., and N. Ramankutty, An oscillation in the global climate system of period 65-70 years, Nature, 367, 723-726, 1994.
Schrader, H., and T. Baumgartner, Decadal variation in upwelling in the central Gulf of California, in Coastal Upwelling, Its Sediment Record, part B, Sedimentary Records of Ancient Coastal Upwelling, edited by J. Thiede and E. Suess, NATO Conf. Ser., 10B, 247-276, 1983.

Schwartz, M., Information Transmission, Modulation, and Noise, 3rd ed., 646 pp., McGraw-Hill, New York, 1980.

Sharp, G.D., Fishery catch records, El Niño/Southern Oscillation, and longer-term climate change as inferred from fish remains in marine sediments, in El Niño: Historical and Paleoclimatic Aspects of the Southern Oscillation, edited by H.F. Diaz and V. Markgraf, pp. 379418, Cambridge Univ. Press, New York, 1992.

Simpson, J.J., A simple model of the 1982-83 Californian "El Niño", Geophys. Res. Lett., 11, 243-246, 1984.

Soutar, A., and J.D. Isaacs, History of fish populations inferred from fish scales in anaerobic sediments off California, Rep. 13, pp. 63-70, Calif. Coop. Oceanic Fish. Invest., La Jolla, 1969.

Stuiver, M., and T.F. Brazunias, Modelling atmospheric $14 \mathrm{C}$ influences and 14C ages of marine samples to $10,000 \mathrm{BC}$, Radiocarbon, 35, 137-189, 1993.

Stuiver, M., and P.J. Reimer, Extended $14 \mathrm{C}$ data base and revised CALIB 3.0 14C age calibration, Radiocarbon, 35, 215-230, 1993.

Thunell, R., C. Pride, E. Tappa, and F. Muller-Karger, Varve formation in the Gulf of California: Insights from time series sediment trap sampling and remote sensing, Quat. Sci. Rev., 12, 451-464, 1993.

Thunell, R.C., C.J. Pride, E. Tappa, and F.E. Muller-Karger, Biogenic silica fluxes and accumulation rates in the Gulf of California, Geology, 22, 303-306, 1994.

Thurow, J., and M. Schaaf, A comparison of Holocene to late Pleistocene grayvalue-time-series of sediments from the Santa Barbara Basin (ODP Site 893) and the Guaymas Basin (DSDP Site 480), in IGCP 374: Palaeoclimatology and Palaeoceanography From Laminated Sediments, 2-6 August 1995, edited by R.J. Behl and J.P. Kennett, 33 pp., Univ. of Calif., Santa Barbara, 1995.

Tiwari, R.K., A Walsh spectral comparison of oxygen $(\delta 180)$ and carbon isotope $(\delta 13 \mathrm{C})$ variations of the Pleistocene bore hole (Eureka 67-135) from the Gulf of Mexico and their orbital significance, Mar. Geol., 78, 167-174, 1987.

Villareal, T.A., and E.J. Carpenter, Nitrogen fixation, suspension characteristics, and chemical composition of Rhizosolenia mats in the central North Pacific gyre, Biol. Oceanogr., 6, 327-345, 1989.

Villareal, T.A., M.A. Altabet, and K. Culver-Rymszoa, Nitrogen transport by vertically migrating diatom mats in the North Pacific Ocean, Nature, 363, 709-712, 1993.

Wyrtki, K., The oxygen minima in relation to ocean circulation, Deep Sea Res., 9, 11-23, 1962.

Wyrtki, K., Circulation and water masses in the eastern equatorial Pacific Ocean, Int. J. Oceanol. Limnol., I, 117-147, 1967.

Yoder, J.A., S. Ackleson, R. Barber, and P. Flamant, A line in the sea, Nature, 371, 689-692, 1994.

A.E.S. Kemp and J. Pike, Department of Oceanography, University of Southampton, Southampton Oceanography Centre, European Way, Southampton, SO14 3ZH, England. (e-mail: aesk@mail.soc.soton.ac.uk; jpl@mail. soc.soton.ac.uk)

(Received April 24, 1996; revised October 8, 1996; accepted October 15, 1996.) 